\title{
ELEŞTİREL DÜŞÜNME ALGISI: LISE ÖĞRETMENLERİ ÜZERİNE BİR ARAŞTIRMA
}

\author{
THE PERCEPTION ON CRITICAL THINKING: A STUDY ON HIGH SCHOOL \\ TEACHERS
}

\author{
Gürcü KOÇ ERDAMAR ${ }^{1}$ \\ Gülgün BANGİR ALPAN ${ }^{2}$
}

\begin{abstract}
$\ddot{O} \mathbf{z}$
$\mathrm{Bu}$ araştırmanın amacı lise öğretmenlerinin eleştirel düşünmeye ilişkin algılarını ortaya koymaktır. Araştırmanın çalışma grubunda, MEB Ortaöğretim Genel Müdürlüğü tarafindan düzenlenen "öğrenme-öğretme kuram ve yaklaşımları" konulu hizmet içi eğitime katılan ve Anadolu Liselerinde görev yapan öğretmenler yer almaktadır. Buna göre araştırmaya katılmayı kabul eden farklı kıdem, yaş, branş ve bölgeden gelen 44 öğretmen ile yürütülen çalışma, olgubilim desenine dayalı olarak tasarlanmıştır. Veriler yarı yapılandırılmış görüşme formu ile toplanmıştır. Öğretmenlerle bireysel görüşmeler gerçekleştirilmiştir. Verilerin analizinde içerik analizi yöntemi kullanılmıştır. Araştırmanın sonunda öğretmenlerin düşünmeyi dar kapsamlı, her insanda bulunan bir yeti, bilgiyi kullanabilme; eleştirel düşünmeyi bilgiyi yorumlama, analiz etme, değerlendirme süreci ve her insanda olmayan, derin ve sistematik bir beceri olarak değerlendirdikleri bulunmuştur. Öğretmenler, özellikle öğrenci görüşlerine saygılı bir öğretmenin ve öğrenci görüşlerinin açığa çıkarıldığı bir öğrenme ortamının eleştirel düşünmeyi desteklediğini vurgulamıştır.
\end{abstract}

Anahtar Kelimeler: Eleştirel düşünme, öğretmen, öğretmen eğitimi.

\begin{abstract}
The main objective of this study is to put forward the perception of high school teachers on critical thinking. The population of the study is comprised of teachers of Anatolian High Schools and who participated in the inservice training titled "teaching-learning theory and approaches" organized by Ministry of National Education Directorate General for Secondary Education. The study which was conducted with the participation of 44 teachers from different regions, age, branch and duration of employment has been designed based on the phenomenological method. The data were collected through semi-structured interview forms. Face-to-face interviews have been performed. The data collected were content-analysed. The results of the study suggest that teachers regards thinking as an ability people have within a limited scope and the use of knowledge; critical thinking as interpreting the knowledge, analysis, evaluation process and a systematic and deep ability not possessed by everyone. Teachers put special emphasis that teachers who respect to the opinions of students and learning setting allowing for the opinions of teachers and students alike support critical thinking.
\end{abstract}

Keywords: Critical thinking, teacher, teacher education.

\footnotetext{
${ }^{1}$ Doç.Dr., Gazi Üniversitesi, Gazi Eğitim Fakültesi, Eğitim Bilimleri Bölümü, gurkoc@gazi.edu.tr

${ }^{2}$ Gazi Üniversitesi, Gazi Eğitim Fakültesi, Eğitim Bilimleri Bölümü, bangir@gazi.edu.tr
} 


\section{GíRiș}

Bir öğretmenin dünyaya eleştirel bir bakış açısıyla yaklaşması ne kadar önemliyse, öğrencilerinin eleştirel düşünme güçlerini desteklemesi de o kadar önemlidir. Ancak eleştirel düşünen bir öğretmen, eleştirel düşünmeyi geliştiren bir öğrenme ortamı oluşturabilir. Eleştirel düşünme ile temel bir bilme edimi olan düşünme arasında ayrım yapmak gerekir. Düşünme bilginin zihinde işlenmesi anlamını taşırken eleştirel düşünme, düşünme üzerine düşünme ve düşünmeyi organize etme işlemidir. Gelder (2005), eleştirel düşünmenin karmaşık olduğunu, her bireyin eleştirel düşünmeyi başaramadığını belirtmektedir. Eleştirel düşünme üst düzey düşünme becerilerinden birisidir. $O$ halde eleştirel düşünme nedir? Eleştirel düşünen bir bireyin özellikleri nelerdir? Eleştirel düşünmenin boyutları nelerdir? Herkes (her öğretmen) eleştirel düşünür olmak zorunda mıdır?

Eleştirel düşünmenin tanımına ilişkin alanyazında pek çok bilgi bulunmaktadır. Eleştirel kelimesi etimelojik olarak iki Yunan kökenli kelimeden türetilmiştir: Kriticos (yargi) ve kriterion (ölçütler). Buna göre eleştirel düşünme en genel anlamda ölçütlere bağlı olarak yargıya varmadır (Paul ve Elder, 2013). Johnson'a (2000) göre eleştirel düşünme örgütleme, analiz etme ve değerlendirme süreçlerini içeren bir düşünme biçimidir. Beyer (1987) eleştirel düşünmeyi bilginin doğruluğunun ve kesinliğinin değerlendirilmesi ile ilişkilendirir. Paul ve Elder'e göre ise (2013) eleştirel düşünme; düşünmeyi analiz etme, düşünmeyi değerlendirme ve düşünmeyi geliştirme olmak üzere iç içe geçmiş üç aşamadan oluşmaktadır. Halpern (1999) eleştirel düşünmeye hem düşünme süreçlerinin hem de ürün olarak ortaya çıkan fikirlerin değerlendirilmesi olarak bakmaktadır. Eleştirel düşünen bireyler bir olayın anlamını ve nedenlerini sorgulamakta, bir bilginin gerçekliğini araştırmakta, eksik ve yanlış bilgiyi ayıklamakta, farklı görüşlerden yararlanarak bilgiyi yeniden organize etmektedir. Başka bir deyişle bu bireyler başkalarının fikrini olduğu gibi kabul etmeyip, fikri analiz etmekte ve kendi düşüncesini oluşturmaktadır (Doğanay ve Ünal, 2006).

Görüldüğü gibi literatürde eleştirel düşünmenin tanımına ve kapsamına ilişkin pek çok açıklama yer almaktadır. 1990 yılında Amerikan Felsefe Derneği'nin desteklediği Delphi projesi kapsamında eleştirel düşünmeyi oluşturan eğilimler ve beceriler araştırılmış ve eleştirel düşünürlerin özellikleri ortaya konmaya çalışılmıştır. Projenin sonunda eleştirel düşünen bireylerin meraklı, sistematik, açık fikirli, doğruyu arama gibi eğilimlere sahip oldukları bulunmuştur (Facione, 1990). Özden'e göre (2005) eleştirel düşünmenin belirleyici özellikleri, önyargıların farkına varma, birincil ve ikincil kaynakları ayırt etme, çıkarımların nedenlerini analiz etme, varsayımları ve iddiaları ayırt etme, bir argümanın eksik taraflarını ve belirsizlikleri görmedir. Cüceloğlu (2008) da eleştirel düşünmenin kalıplaşmış insan paradigmasına değil gelişmiş insan paradigmasına uygun olduğunu belirtmektedir. $\mathrm{Bu}$ nedenlerle eleştirel düşünme tüm eğitim programlarının öğrencilere kazandırmayı hedeflediği bir beceridir (Bailin, 2002; Smith, 2003).

Paul, Binker, Jensen ve Kreklau'ya göre eleştirel düşünme duyuşsal ve bilişsel-makro ve bilişsel-mikro stratejiler olmak üzere üç boyutta incelenebilir (Akt. Paul, 1992). Duyuşsal boyutta empatik olmak, tarafsız düşünmek, farklı görüşlere ve aykırı düşüncelere açık olmak, belirsizlikleri ve değişimi kabullenmek, iyi niyetli olmak, sorgulama cesareti geliştirmek gibi stratejiler yer almaktadır. Eleştirel düşünmenin bilişsel-makro boyutunu geçerli ve geçersiz genellemeleri fark etmek, sorunları açık hale getirmek, değerlendirme için ölçüt geliştirmek, bilgi kaynağının güvenirliğini sorgulamak, eleştirel okumak ve dinlemek, çözüm üretmek; bilişsel-mikro boyutunu ise ideal ile gerçeği ayırt etmek, benzerlik ve farklılıkları belirlemek, ilgili olanı olmayandan ayırt etmek, çelişkileri fark etmek, akılcı yorumlar yapmak gibi 
stratejileri kapsamaktadır. $O$ halde eleştirel düşünme hem bağımsız hem de üst düzey düşünmeyi gerektirmektedir.

Herkesin eleştirel düşünür olması beklenemez ama öğretmenlerin eleştirel düşünür olması istenen bir durumdur. Çünkü ancak eleştirel düşünen bir öğretmen, eleştirel düşünen öğrenciler yetiştirebilir. Ancak ülkemizde öğretmen ve öğretmen adayları ile gerçekleștirilen birçok çalışmada eleştirel düşünme beceri ve eğilimlerinin yetersiz düzeyde olduğu bulgulanmıştır (Zayif, 2008; Bulut, Ertem ve Sevil, 2009; Şen, 2009; Şengül ve Üstündağ, 2009; Korkmaz, 2009; Beşoluk ve Önder, 2010; Kızıltaş, 2011; Şenlik, Balkan ve Aycan, 2011; Torun, 2011; Tümkaya, 2011; Kuvaç ve Koç, 2014; Açışl1, 2016; Pekdoğan ve Bayar, 2016). Oysa üniversite eğitiminin öğretmen adaylarına üst düzey düşünme becerilerini kazandırması beklenmektedir. Diğer yandan çalışmalarda öğretmen ve öğretmen adaylarının eleştirel düşünme becerilerinin genelde düşük çıkmasının birçok nedeni olabilir. $\mathrm{Bu}$ nedenlerden birisi, örneklem ve ölçek farklılıklarından kaynaklanmış olabileceği yönündedir. Anılan araştırmalarda en fazla tercih edilen yöntemin nicel, en fazla kullanılan ölçme aracının da California Eleştirel Düşünme Eğilimi (CEDÖ) ölçeği olduğu görülmektedir. CEDÖ’nün kullanıldığı çalışmaların çoğunda, öğretmen adaylarının ve öğretmenlerin eleştirel düşünme eğilimleri yetersiz bulunmuştur. Bu nedenle bu çalışmada nitel araştırma yöntemi tercih edilmiş ve öğretmenlerin eleştirel düşünmeye yönelik görüşleri ayrıntılı analiz edilmeye çalışılmıştır. Ayrıca öğretmenlerin eleştirel düşünmeye ilişkin görüşlerinin incelendiği bir çalışmaya rastlanmamış olması, araştırmanın alan yazına katkı sağlayacağını düşündürmektedir. Buna göre bu araştırmanın amacı Anadolu Liselerinde görev yapan öğretmenlerin eleştirel düşünme algılarını, sınıflarında eleştirel düşünmeyi geliştirmek için neler yaptıklarını ve öğrenme ortamında uygulanabilirliğine ilişkin görüşlerini saptamaktır.

\section{YÖNTEM}

\section{Araştırma Modeli}

Çalıșmada nitel araștırma yöntemlerinden olgubilim deseni kullanılmıștır. Bu desen kullanılarak öğretmenlerin eleştirel düşünmeyi nasıl algıladıkları ve sınıflarında ne tür uygulamalar yaptıkları belirlenmeye çalışılmıştır. Öğretmenlerin eleştirel düşünme algılarını belirlemek için yarı yapılandırılmış görüşme tekniğinden yararlanılmıştır. Görüşmenin amacı bir bireyin bakış açısını, perspektifini anlayabilmektir (Yıldırım ve Şimşek, 2013). Yarı yapılandırılmış görüşmeler sayesinde bireylerin algıları, görüşleri düşünceleri vb. derinlemesine incelenebilir. Bu çalışmada öğretmenlerin eleştirel düşünme algıları varolduğu biçimiyle tanımlanmaya çalışılmıştır.

\section{Çalışma Grubu}

Araştırmanın çalışma grubunu 11-15 Nisan 2016 tarihlerinde MEB ortaöğretim genel müdürlüğü tarafından Rize'de düzenlenen "öğrenme-öğretme kuram ve yaklaşımları" konulu hizmet içi eğitim seminerine katılan ortaöğretim kurumlarında (Anadolu liselerinde) görev yapan öğretmenler oluşturmaktadır. Seminere katılan 86 öğretmenden 44 tanesi çalışmaya gönüllü olarak katılmayı kabul etmiştir. Öğretmenlerin farklı branş ve bölgelerde öğretmenlik yapıyor olmasına özen gösterilmiştir. Öğretmenlere ilişkin demografik bilgiler Tablo 1'de sunulmuştur.

Öğretmenlerin \%79.2'si erkek, \%20.8'i kadın; \%33.0’ü 11-15 yıl, \%25.5'i 16-20 yıl kıdeme sahip; \%33.0'ü 36-40 yaş, \%27.4'ü 41-45 yaş aralığında; \%26.42'ü Türkçe/Türk Dili ve Edebiyatı, \%26.4'ü Sosyal Bilimler, \%18.9'u Diğer (Yabancı dil-Beden Eğitimi-MüzikGörsel Sanatlar), \%16.0'sı Fen Bilimleri, \%12.3'ü Matematik branşında ve \%22.6'sı Akdeniz 
ve Güneydoğu Anadolu, \%15.1'i Marmara, \%14.2'si İç Anadolu, \%9.4'ü Ege ve Doğu Anadolu ve \%6.6'sı Karadeniz Bölgesinde öğretmenlik yapmaktadır.

Tablo 1. Öğretmenlere İlişsin Demografik Bilgiler

\begin{tabular}{llll}
\hline Demografik değişkenler & Özellikler & f & $\%$ \\
\hline Cinsiyet & Kadın & 22 & 20.8 \\
& Erkek & 84 & 79.2 \\
Kıdem & $10-$ & & \\
& $11-15$ & 25 & 23.6 \\
& $16-20$ & 35 & 33.0 \\
& $21+$ & 26 & 25.5 \\
& & 20 & 18.9 \\
Yaş & $35-$ & & \\
& $36-40$ & 27 & 25.5 \\
& $41-45$ & 35 & 33.0 \\
& $45+$ & 29 & 27.4 \\
Branş & Türkçe/Türk Dili ve Ede. & 15 & 14.2 \\
& Fen Bilimleri & 28 & 26.4 \\
& Matematik & 17 & 16.0 \\
& Sosyal Bilimler & 13 & 12.3 \\
& Diğer & 28 & 26.4 \\
& & 20 & 18.9 \\
İç Anadolu & & \\
& Marmara & & \\
& Akdeniz & 15 & 14.2 \\
& Karadeniz & 16 & 15.1 \\
& Ege & 24 & 22.6 \\
& Güneydoğu Anadolu & 7 & 6.6 \\
& Doğu Anadolu & 10 & 9.4 \\
& & 24 & 22.6 \\
& & 10 & 9.4 \\
\hline
\end{tabular}

\section{Veri Toplama Aracı}

Veri toplama aracı olarak yarı yapılandırılmış görüşme formu kullanılmıştır. Hazırlanan sorular anlaşılırlığı ve veri toplamaya uygunluğu açısından üç eğitim bilimleri (eleştirel düşünme alanında çalışan) uzmanı tarafından incelenmiş daha sonra iki öğretmen ile ön denemesi gerçekleştirilmiştir. Buna göre formda altı soru yer almıştır. Görüşmeler bireysel olarak gerçekleştirilmiş, 10-25 dakika arasında sürmüştür. İzin veren katılımcıların görüşleri ses kaydına alınmış, diğerleri için elle notlar tutulmuştur. Ses kaydı alınan görüşler yazıya geçirilmiştir. Veriler 11-15 Nisan 2016 tarihlerinde toplanmıştır.

\section{Verilerin Analizi}

Veriler analiz edilmeden önce 44 görüşme okunmuş ve genel bir fikir edinilerek bir kod listesi hazırlanmıştır. Daha sonra her görüşme, bu kod listesinden yararlanılarak tek tek analiz edilmiştir. Kod listelerinden birbirleriyle ilişkili olanlar bir araya getirilerek tematik kodlama yapılmıştır. Tematik kodlamalarda araştırmanın soruları ile olan iç ve dış tutarlılığa dikkat edilmiştir. Ayrıca daha sonra katılımcıların görüşleri bu kod ve tema listesi göz önünde bulundurularak gruplanmış ve araştırma soruları doğrultusunda bulgu başlıkları oluşturulmuştur. Analiz sonucunda beş temaya ulaşılmış ve kodlar bu temaların altında toplanmıştır. Kodların güvenirliğini sağlamak amacıyla tesadüfi seçilen bir görüşme formu 
her iki araştırmacı tarafından ayrı ayrı kodlanmış ve Miles ve Huberman'ın (1994) formülü kullanılarak güvenirlik katsayısı 0.82 olarak hesaplanmıştır.

\section{BULGULAR}

Bulgular öğretmenlerin eleştirel düşünmenin ne olduğuna ilişkin görüşleri, düşünme ve eleştirel düşünmeye bakış açısı, eleştirel düşünen öğretmenlerin özellikleri, öğretmenlerin uyguladığı eleştirel düşünme etkinlikleri ve eleştirel düşünmeyi geliştirici öneriler olmak üzere beş temada toplanmıştır.

\section{Öğretmenlerin Eleştirel Düşünme Algıları}

Öğretmenlerin eleştirel düşünmenin ne olduğuna ilişkin açıklamaları Tablo 2'de görülmektedir.

Tablo 2. Öğretmenlere Göre Eleştirel Düşünme

\begin{tabular}{ll}
\hline Eleştirel Düşünme & $\mathrm{f}$ \\
\hline sorgulama & 12 \\
analiz etme & 11 \\
üst düzey düşünme becerisi & 8 \\
düşünme üzerine düşünme & 7 \\
değerlendirme & 6 \\
farklı açılardan düşünme & 6 \\
yorumlama & 5 \\
olduğu gibi kabul etmeme & 5 \\
bilgileri örgütleme & 5 \\
açılama & 4 \\
önyargisiz düşünme & 3 \\
değişik çözüm yolları sunma & 1 \\
\hline
\end{tabular}

Öğretmenler sizce eleştirel düşünme nedir sorusuna en fazla sorgulama, analiz etme, üst düzey düşünme becerisi, düşünme üzerine düşünme, değerlendirme ve farklı açılardan düşünme cevaplarını vermişlerdir. Öğretmenlerden bazıları da eleştirel düşünmeyi yorumlama, açıklama, önyargısız düşünme, bilgileri örgütleme ve değişik çözüm yolları oluşturma olarak değerlendirmektedir. Öğretmen görüşlerinden bazı alıntılara aşağıda yer verilmiştir.

\footnotetext{
Eleştirel düşünme, akll yürütme, analiz ve değerlendirme gibi zihinsel süreçlerden oluşan düşünme biçimidir.

Eleştirel düşünme sorgulamaktır. Bilgiyi doğrudan kabul etmek yerine kendi akıl süzgecinden geçirmektir.

Safsatalara inanmadan, kesin hükümlere varmadan sorunu fark edebilme ve anlamlandırma faaliyetidir. İnsanın içinde bulunduğu çevreyi anlama çabasıdır. Üst düzey düşünme becerisidir. Analiz etme, açılklama ve yorumlama gerektirir.

Bir bilginin doğruluğuna ulaşıncaya kadar devam eden sorgulama sürecidir.
}

Görüldüğü gibi, öğretmenler sorgulama ve yorumlama becerilerinin eleştirel düşünmenin temeli olduğunu düşünmektedir. Amerikan Felsefeciler Birliği'ne göre (Facione ve Facione, 1996) eleştirel düşünen bir bireyin en önemli özellikleri sürekli soru sormas1, görüşlerini desteklemek için kanıtlar araması ve yargıya varabilmek için tüm verileri inceleyip analiz etmesidir. Başka bir deyişle karşılaşılan bir bilgiyi sorgulamadan eleştirel düşünme gerçekleştirilemez. 


\section{Öğretmenlere Göre Düşünme ve Eleştirel Düşünme}

$\mathrm{Bu}$ temada öğretmenlerin düşünme ve eleştirel düşünmeye bakış açıları analiz edilmiştir. Öğretmenlere göre düşünme, bilginin etkin bir biçimde kullanılması, öznel, eleştirel düşünmeye göre daha dar kapsamlı ve yüzeysel, çevreyi anlama çabası, her insanda bulunan bir özellik, akıl yürütme ve çözüm arayışı olarak değerlendirilmiştir. Eleştirel düşünme ise, bir önceki temada da anlatıldığı gibi, bilgiyi yorumlama, anlamlandırma, analiz etme, değerlendirme, sonuçlara ulaşma ve atıl bilgiden kurtulma olarak görülmektedir. Öğretmenler eleştirel düşünmenin, düşünme üzerine kurulduğunu, her insanda olmadığını, düşünmeye göre daha nesnel, derin ve sistematik olduğunu belirtmiştir.

Tablo 3. Öğretmenlere Göre Düşünme Ve Eleştirel Düşünme Kıyaslaması

\begin{tabular}{|c|c|c|c|}
\hline Düşünme & f & Eleştirel düşünme & $\mathrm{f}$ \\
\hline Bilgiyi etkin kullanabilme & 10 & Bilgiyi yorumlama, anlamlandırma, analiz & 12 \\
\hline Öznel, dar kapsamlı, yüzeysel, rastlantısal & 5 & etme, değerlendirme ve sonuç çıkarma & \\
\hline $\begin{array}{l}\text { Çevreyi anlama çabası ile gerçekleştirilen } \\
\text { zihinsel etkinlik }\end{array}$ & 3 & $\begin{array}{l}\text { Düşünme üzerine düşünme, üst düzey } \\
\text { düşünme }\end{array}$ & 8 \\
\hline Tüm insanlarda olan bir yeti & 2 & Atıl bilgiden kurtulma & 6 \\
\hline Akıl yürütme & 2 & Her insanda olmayan bir yeti & 5 \\
\hline \multirow[t]{2}{*}{ Çözüm arayışı } & 2 & Neden sorusunu sorarak düşünme & 5 \\
\hline & & Nesnel, geniş kapsamlı, derin, sistematik & 5 \\
\hline
\end{tabular}
şekildedir:

Öğretmenlerin düşünme ve eleştirel düşünmeye ilişkin görüşlerinden bazı alıntılar şu

Herkes düşünür, ama herkes eleștirel düşünemez.

Düşünme temel bir bilme edimidir, bilgiyi etkin kullanabilmektir. Eleştirel düşünme ise neden sorusunu sorarak düşünmektir.

Düşünme yetisine tüm insanlar sahiptir. Ancak her insan olayları farklı açılardan göremez ve kritik edemez.

Düşünme bir akll yürütmedir, eleștirel düşünme ise bilgiyi analiz ederek atıl bilgiden kurtulmayl sağlar.

Düşünme dar kapsamll ve rastlantılara dayall, eleştirel düşünme ise çok daha kapsaml, detaycı ve sistematiktir.

Duron, Limbach ve Waugh (2006)'a göre de düşünme her insanda bulunur. Ancak tek başına eksik ve yetersiz kalabilmektedir. Eleştirel düşünmeyi düşünmeden ayıran en önemli fark, eleştirel düşünmenin amaçlı ve sistematik bir biçimde gerçekleşmesi, önyargılardan uzak durması, analiz, sentez ve değerlendirmeye dayanmasıdır (Gaforth, 1999). İpşiroğlu'na göre (2004) eleştirel düşünme, düşünmenin en gelişmiş ve ileri biçimidir. Çünkü eleştirel düşünme düşünmeye göre daha nesnel, derinlemesine ve saplantısız olma özelliklerini taşır. $O$ halde eleştirel düşünme, düşünmenin üzerine kurulmaktadır. Öğretmenlerin genel olarak düşünme ve eleştirel düşünme arasında kuramsal açıdan doğru bir ayrım yapabildiği söylenebilir.

\section{Eleștirel Düşünen Öğretmenlerin Özellikleri}

Öğretmenlere göre eleştirel düşünen öğretmenlerin taşıması gereken özellikler Tablo 4'de verilmiştir. 
Tablo 4. Eleştirel Düşünen Öğretmen

\begin{tabular}{ll}
\hline Öğretmen & $\mathrm{f}$ \\
\hline öğrenci görüşlerine saygı duymalı & 12 \\
öğrenciye eleştirel düşünme konusunda model olmalı & 12 \\
demokratik ve güvenli bir öğrenme ortamı oluşturmalı & 10 \\
alanındaki yenilikleri izlemeli & 7 \\
öğrenciyi dinlemeli & 6 \\
eleştiriye açı olmalı & 5 \\
önyargısı olmalı & 5 \\
farklı yöntem-teknikler kullanarak öğrencilerin bireysel farklılıklarına hitap & 3 \\
etmeli & \\
\hline
\end{tabular}

Tablo 4'e göre eleştirel düşünen bir öğretmenin en önemli özellikleri öğrenci görüşlerine sayg1 duyması, kendisi eleştirel düşünerek öğrenciye model olması ve eleştirel düşünmenin gelişmesi için gerekli demokratik, özgür ve güvenli bir öğrenme ortamını oluşturmasıdır. Parmaksız da (2015) eleştirel düşünmenin gelişiminde eğitim sisteminin demokratikleşmesinin önemini vurgulamaktadır.

Öncelikle ögrretmenin eleştirel düşünmesi ve öğrenciye bunu kazandirmak için istekli olması gerekir. Eleştirel düşünmeyi ögrenmek, ögrenciye yalnızca derslerde değil yaşamının her alanında farkındalık sağlar.

Öğretmenin eleştirel düşünmeye açık olmast ve kendisinin model olması gerekir.

Öğretmenin tutumu, en önemli etken bence. Öğretmen farkl görüss açılarına saygı duymal, ögrrenciyi dinlemelidir.

Özgür bir sinıf ortamı, düşünceye saygll, demokratik bir atmosfer. Öğretmen bunu yapabiliyorsa eleştirel düşünmeyi destekleyebilir.

Bazı öğretmenler ise eleştirel düşünen bir öğretmenin alanındaki yenilikleri izlemesi gerektiğini, öğrenciyi dinlemesi, eleştirilere açık ve önyargısız olması ve farklı öğretim yöntemleri kullanarak bireysel farklılıkları dikkate alması gerektiğini belirtmiştir.

\section{Öğretmenlerin Uyguladığı Eleştirel Düşünme Etkinlikleri}

Öğretmenlere sınıflarında eleştirel düşünmeyi geliştirmek için ne tür etkinlikler uyguladıkları sorulmuştur. Yanıtlar incelendiğinde öğretmenlerin eleştirel düşünmeyi geliştirdiğini düşündükleri ve sınıflarında en fazla kullandıkları etkinliklerin öğrenci görüşlerini açığa çıkarma, soru sorma, sorgulama ve araştırma, beyin fırtınası ve tartışma olduğu saptanmıştır. Literatürde eleştirel düşünmeyi geliştirmek için sorunlara çok boyutlu bakabilme, karşı görüşün dayanaklarını inceleme, kendi görüşlerinin dayandığı kanıtları paylaşma gibi öğrencilerin kendisinin ve başkalarının görüşlerini karşılaştırıp bir senteze ulaştığ1 etkinliklerin düzenlenmesinin öneminden söz edilmektedir (Alkın-Şahin ve Gözütok, 2013; Parmaksız, 2015). 
Tablo 5. Öğretmenlerin Uyguladığı Eleştirel Düşünmeyi Geliştirici Etkinlikler

\begin{tabular}{ll}
\hline Etkinlikler & $\mathrm{f}$ \\
\hline öğrenci görüşlerini açı̆̆a çıkarma & 11 \\
soru sorma & 11 \\
sorgulama ve araştırma & 7 \\
beyin firtınası & 7 \\
tartışma & 6 \\
örnek olay analizi & 5 \\
araştırma ödevleri & 3 \\
değerlendirme & 3 \\
yapilandırılmamış problemler & 2 \\
düşünme ödevleri & 2 \\
\hline
\end{tabular}

Bana yeni bir örnek verebilir misin? Bu senin temel görüşün mü? Senin çözüm önerinin etkili olduğunu nasil kanitlarsin? gibi sorular sorartm.

Osmanl Devleti bir okyanuslar devleti olabilir miydi? Evet diyenlerin de haylr diyenlerin de cevaplarin ve gerekçelerini dinleyip karar veriyoruz. Bazen sadece düşünme ödevleri veriyorum.

Konuyla ilgili bir düşünce ortaya atar ve siz ne düşünüyorsunuz diye sorarım.

Öğrenci bir fikir belirttiğinde «neden» sorusunu sormak çok önemli. O zaman eleştirel düşünmeye başllyor.

Ben tarih dersinde bir antlaşmayı işleyeceksem antlaşmanın maddelerini, içinde bulunulan zamanı ve koşulları dikkate alarak analiz etmelerini ve değerlendirmelerini isterim.

Dersimde en çok kullandiğım sorular. Neden, nasıl, niçin? Peki şöyle olsaydl nasıl olurdu diye soruyorum. Düşünmek zor geliyor bazen... Ama öğrenciler alıştıkça çok eğlenceli ve ilginç fikirler ortaya çıklyor.

Öğretmenlerin uyguladığı etkinlikler incelendiğinde, eleştirel düşünmenin duyuşsal boyutuna ağırlık verdikleri, bilişsel stratejileri daha az dikkate aldıkları görülmektedir. Bilişsel stratejiler kapsamında geçerli ve geçersiz genellemelerin belirlenmesi, sayıltıların incelenmesi, değerlendirme ölçütlerinin oluşturulması, bilgi kaynağının güvenirliğinin kontrol edilmesi, görüşlerin, inançların ve yorumların analizi, çelişkilerin fark edilmesi ve uygun çözümlerin üretilmesi gibi etkinliklere yer verilmelidir. Öğretmenlerin sınıflarında uyguladıkları etkinliklerin çok azı eleştirel düşünmeyi geliştirici bilişsel stratejidir. Örnek olay ve yapılandırılmamış problemlerin analizini yaptıran ve düşünme ödevleri veren öğretmenler bulunmakla birlikte, sayıları oldukça azdır.

\section{Eleştirel Düşünmeyi Geliştirici Öneriler}

Eleştirel düşünmeyi geliştirici öneriler temasında dört alt kod yer almıştır. Öğretmen, öğrenme-öğretme süreci, öğrenci ve aile boyutlarında öneriler geliştirilmiştir.

Öğretmene yönelik önerilerden ilk sırada, eleştirel düşünen öğretmenin özelliklerinde olduğu gibi, öğrenci görüşlerine değer vermeli yer almaktadır. Benzer biçimde öğretmenin düşünmeye yönelik etkinlikler düzenlemesi, eleştirel düşünmeye model olması, demokratik olması önerilmektedir. İlginç önerilerden birisi de öğretmenlerin öğrencilerin safsataya düşmelerini engellemesi olarak belirtilmiştir.

Neden sorusunu sıkça sorarım. «Böyleymiş, duydum» yerine «yaptı̆̆ım araştırmalardan şu sonuçlara ulaştım» demelerini desteklerim.

Öğrencilerinin safsataya düşmelerini engellemelidir. Ayrıca «doğru tek değildir» algısını yerleştirmelidir. Bunun için de demokratik bir ortama gerek var.

Öğretmen eleştiriye açık olmalı. Kitap okumalı, tartışma programları izlemeli, konferanslara katılmalı. Eleştirel gözle yaklaşmalı, bilginin doğruluğunu araştırmalı. Yani önce kendisi örnek olmall.

Öğretmen ögrencilere her firsatta kendini ifade firsatı vermeli, farklı bakış açılarını desteklemelidir. 
Tablo 6. Öğretmenlerin Bakış Açısından Öneriler

\begin{tabular}{|c|c|c|}
\hline Öneriler & & $\mathrm{f}$ \\
\hline \multirow[t]{8}{*}{ Öğretmen } & öğrencilerin görüşlerine değer vermeli & 21 \\
\hline & düşünmeye, sorgulamaya yönelik etkinlikler düzenlemeli & 15 \\
\hline & kendini yenilemeli, yeniliklere açık olmalı & 9 \\
\hline & rol model olmalı & 9 \\
\hline & özgür ve demokratik öğrenme ortamları oluşturmalı & 6 \\
\hline & öğrencilerin safsataya düşmesini engellemeli & 4 \\
\hline & okuma kültürü geliştirilmeli & 10 \\
\hline & eğitim programlarında eleştirel düşünmeye yer verilmeli & 8 \\
\hline & öğrenci sayıları az olmalı & 5 \\
\hline \multirow{4}{*}{ öğretme süreci } & ölçme-değerlendirme sistemi değiştirilmeli & 2 \\
\hline & içerik azaltılmalı & 1 \\
\hline & $\begin{array}{l}\text { tek cevapla yetinmemeli, araştırmalı ve sorgulamalı, } \\
\text { meraklı olmalı }\end{array}$ & 15 \\
\hline & okumaya, öğrenmeye ve bilgiyi kullanmaya istekli olmalı & 13 \\
\hline \multirow[t]{7}{*}{ Öğrenci } & farklı görüşlere saygılı olmalı & \\
\hline & çevresine duyarlılık göstermeli & 9 \\
\hline & & 3 \\
\hline & çocuklarına saygı duymalı & \\
\hline & önemli kararlarda çocuklarının da görüşünü almalı & 9 \\
\hline & rol model olmalı & 6 \\
\hline & demokratik aile tutumuna sahip olmalı & 6 \\
\hline \multirow[t]{4}{*}{ Aile } & öğretmen ile işbirliği yapmalı & 5 \\
\hline & eleştirilere açık olmalı & 4 \\
\hline & çocuğunun olumlu davranışlarını desteklemeli & 3 \\
\hline & & 3 \\
\hline
\end{tabular}

Öğretmenler öğrenme-öğretme sürecine yönelik olarak da önerilerde bulunmuştur. En dikkate değer öneriler öğrencilerde okuma kültürünün geliştirilmesi ve eğitim programlarında eleştirel düşünme becerisine yer verilmesidir. Bazı öğretmenler ders içeriklerinin ve öğrenci sayılarının azaltılması ve ölçme-değerlendirme sisteminin değiştirilmesi ile eleştirel düşünmenin daha fazla gelişeceğini savunmaktadır.

Eleştirel düşünmenin gelişmesi için okuma kültürü geliştirilmeli. Daha çok okumaya ihtiyacımız var.

Bu kadar çok ögrenci ve konu ile eleştirel ve yaratıcı düşünceyi geliştirmek çok zor.

Öğrencilere yönelik öneriler tek cevapla yetinmeyip araştırma ve sorgulamaları, okumaya, öğrenmeye istekli ve meraklı olmaları ve farklı görüşlere saygılı olmaları yönündedir.

Öğrenci tek cevapla yetinmemeli, yeni fikirlerin peşinde olmall. Farklı düşünceleri, soru sormayı desteklemeliyiz.

Öğretmenler ailelerin de eleştirel düşünmeyi geliştirici rollerine ilişkiler öneriler getirmiştir. Aileler çocuklarına saygı duymalı, önemli kararları çocukları ile birlikte almalı, demokratik aile tutumuna sahip olmalı ve rol model olmalıdır.

Baskıcı bir ailede eleştirel düşünme çok az gelişir.

Ev ortamında da çocuğun değer ve kabul görmesi, düşüncelerini rahatça ifade edebilmesi önemli. 


\section{SONUÇ ve ÖNERILER}

Eleştirel düşünmenin farklı kaynaklardan veri toplama, verilerden yola çıkarak bir karara varma, önemli ilişkileri kurabilme, bir bilginin doğruluğunu/yanlışlığını değerlendirebilme olduğu söylenebilir. Öğretmenler de eleştirel düşünmenin sorgulama, analiz ve değerlendirme boyutları üzerinde daha fazla yorum yapmışlardır. Bazı öğretmenler eleştirel düşünmenin, düşünme üzerine düşünmeyi sağlayan üst düzey bir beceri olduğunu vurgulamıştır. Öğretmenlerin eleştirel düşünmeye ilişkin kuramsal bilgilerinin yeterli olduğu düşünülebilir. Çünkü öğretmenler düşünme ve eleştirel düşünme arasındaki farkı oldukça somut bir biçimde ortaya koymuştur. Buna göre düşünme her insanda olan, dar kapsaml, yüzeysel, bilginin sadece kullanımını ifade ederken; eleştirel düşünme öğretmenler tarafından her insanda olmayan ancak geliştirilebilen, nesnel, derinlemesine ve sistematik düşünme, düşünme üzerine düşünme olarak algılanmıştır. Aybek (2015) de olağan düşünmenin anlamlandırma, bağıntıları test etme, kanıtsız düşünme sunma, bir ölçüte dayanmadan kararlar alma gibi özelliklerinin olduğunu, eleştirel düşünmenin ise değerlendirme, karar verme ve kanıta dayalı düşünceler sunmayı içerdiğini belirtmektedir.

Öğretmenler, eleştirel düşünmeyi geliştiren bir öğretmenin, öğrenci görüşlerine sayg1 duyan, demokratik bir öğrenme ortamı oluşturan, eleştirel düşünme konusunda model olan ve alanındaki yenilikleri izleyen bir öğretmen olması gerektiğini düşünmektedir. Öğretmen davranışlarının eleştirel düşünmenin gelişiminde eleştirel düşünmenin doğrudan öğretiminden daha etkili olduğu vurgulanmaktadır (Tabor, 1988; Innabi, 2003). Walsh ve Paul (1998) öğretmenlerin hizmet öncesi ve hizmet sırasında eleştirel düşünme beceri eğitimi almaları gerektiğini, ancak bu sayede öğrencilerine örnek olabileceklerini belirtmektedir. Anlatım yöntemini sıklıkla kullanan, öğrenci görüşlerini önemsemeyen, bilimsel problem çözme yöntemlerine yer vermeyen bir öğretmenin sınıfında öğrencilerin eleştirel düşünmesi beklenemez. Eleştirel düşünmeyi desteklemek için bir öğretmenin, öğrencilerine düşündürücü sorular sorması, fikirlerin altında yatan nedenleri ve kanıtlarını sorgulamayı kazandırması son derece önemlidir.

Öğretmenlerin eleştirel düşünmeyi geliştirmek için en fazla gerçekleştirdikleri öğrenme etkinlikleri, öğrenci görüşlerini açığa çıkarma, soru sorma, beyin fırtınası, düşünme ve sorgulama çalışmaları ve tartışmalardır. Narin (2009) ve Yıldırım (2005) çalışmalarında, eleştirel düşünme gücü yüksek öğretmenlerin öğretim yöntemlerini daha etkili kullandıklarını bulgulamıştır. Öğretmenlerin sınıflarında uyguladıkları etkinliklerin daha çok sosyal etkileşime dayalı ve görüşlerin paylaşılmasına olanak tanıyıcı nitelikte olduğu görülmektedir. Tabii ki, öğrencinin neyi nasıl düşündüğünün ortaya çıkarılması, tartışma etkinliklerinin düzenlenmesi ile sağlanabilir. Ancak öğretmenlerin eleştirel düşünmenin bilişsel boyutuna ilişkin pek fazla öğrenme etkinliği düzenlemediği görülmektedir. Oysa eleştirel düşünmenin gelişebilmesi için bilişsel stratejilere de ihtiyaç vardır. Ayrıca öğretmenlerin eleştirel düşünmenin ne olduğuna ilişkin cevapları, analiz, sentez yapma, soruşturma, yorumlama, değerlendirme ve yargıya ulaşma gibi bilişsel boyutla daha yakından ilişkili kavramlara odaklanmıştır. Potts (1994) Eleştirel Düşünme Öğretimi İçin Öneriler isimli çalışmasında öğretmenlerin, açık uçlu sorular sorma, bilgiler arasındaki analojileri buldurma, problem çözerken bilginin doğruluğunu araştırma, problemlere farklı çözüm yolları önerme gibi bilişsel stratejilere yer vermeleri gerektiğini belirtmektedir.

Öğretmenlerin eleştirel düşünme becerilerini geliştirmeye yönelik etkinlikleri sınıflarında uygulamaları, öğrencilerin bireysel farklılıklarını dikkate alacağı için öğrenci başarısını ve derse yönelik tutumunu olumlu yönde etkileyecektir. Bu nedenle öncelikle öğretmenlerin eleştirel düşünme becerileri geliştirilerek, sınıflarında eleştirel düşünmenin gelişimine önem vermeleri sağlanmalıdır. Bu amaçla hem hizmet öncesi öğretmen yetiştirme 
programlarında, hem de hizmet içi eğitimlerde eleştirel düşünme kuramsal ve uygulamalı olarak ele alınmalı, etkinliklerle nasıl geliştirilebileceğine örnek olunmalıdır. Aybek (2015) eleştirel düşünme eğitimi ile öğrencilerin karşılaştıkları sorunları daha etkili çözeceklerini ve yaşam kalitelerinin yükseleceğini vurgulamaktadır.

Eleştirel düşünmenin öğretimine yoğunlaşmış olan çalışmalar etkin öğrenme, işbirliğine dayalı öğrenme, tartışma ve proje tabanlı öğretim yöntemlerinin etkili olduğunu (Hoaglund, 1993; Ten Dam ve Volman, 2004; Gokhale, 2012; Kim, Sharma, Land ve Furlong, 2013; Lu, Ho, Hau ve Lai, 2014) ancak eleştirel düşünme gelişiminin yavaş gerçekleştiğini, psikolojik, sosyal ve kültürel etkenlerin de dikkate alınması gerektiğini vurgulamaktadır (Schafersman, 1991; Wolcott, Baril, Cunningham, Fordham ve Pierre, 2002). Eleştirel düşünmenin geliştirilmesi için öğretmenin yanında öğrenci ve aileye de sorumluluklar düşmektedir. Aile de çocuğunu birey olarak görmeli, saygı duymalı, görüşlerine değer vermeli ve demokratik bir tutum sergilemelidir. Öğrenci ise öğrenmeye meraklı ve istekli olmalı, farklı görüşlere açık olmalı, bilgiyi araştırmalı ve sorgulamalıdır. Sorgulama gücü yüksek bir bireyin, eleştirel düşünme kapasitesinin yüksek olacağı düşünülmektedir. Yazçayır (2015) da, her konu alanına duyarlı, araştıran ve doğru düşünerek edindiği bilgiyi günlük yaşamında kullanan öğrenciler yetiştirilmesi gerektiğini vurgulamaktadır. Branch'a (2000) göre, eleştirel düşünme becerilerini kullanan bireylerin özellikleri meraklılık, açık görüşlülük, sistematiklik, çözümleyicilik, entelektüel olgunluk, özgüven sahibi olma ve doğruyu aramadır. Merak, eleştirel düşünmenin önemli bir boyutunu oluşturduğu için eleştirel düşünmeyi araştıran çalışmalarda göze çarpmaktadır. Merak ilgimizi çeken ve bizi bir araştırmaya yönlendiren içsel bir güçtür (Loewenstein, 1994). Bu açıdan bakıldığında merakla eleştirel düşünme arasında sıkı bir bağ olduğu, merak duygusunun bireyi eleştirel düşünmeye yönelttiği söylenebilir. Araştırmalarda eleştirel düşünce ile merak arasında anlamlı pozitif yönde ilişki bulunmuştur (Muis, Psaradellis, Lajoie, Leo ve Chevrier, 2015; Uluçınar ve Aypay, 2016). Ülkemizdeki başka bir çalışmada ise öğretmen adaylarının bir bilginin doğruluğunu araştırmadan inandıkları ve sorgulamadan kullanmaya yöneldikleri bulunmuştur (Korkmaz, 2009). Bu anlamda öğretmenlerin öğrencilerinden meraklı olmalarını istemeleri, eleştirel düşünmenin geliştirilmesi açısından önemlidir.

Son olarak öğrenme ortamları öğrencilere okuma kültürü kazandırmalı, eleştirel düşünme becerilerine eğitim programlarında yer verilmelidir. Çünkü Maltepe'nin (2016) çalışmasında da ortaya konduğu gibi bir yılda altı ve üzerinde kitap okuyan öğretmen adaylarının eleştirel düşünme eğilimleri daha az kitap okuyanlara göre daha yüksektir. İpşiroğlu (2004) eleştirel düşünme öğretimi ile okuma alışkanlığı arasındaki ilişkiden söz etmiş, farklı bakış açılarının kazandırılması, çok yönlü düşünmenin öğretilmesi ve hayal gücünün desteklenmesi açılarından okuma kültürünün geliştirilmesinin önemine değinmiştir. Okuduğu bilgileri sentezleyen ve geniş bir dünya kültürüne sahip olan bir bireyin, eleştirel düşünür olma olasılığı da yüksek olacaktır. Eisntein'1n da belirttiği gibi “evrende en büyük ziyan, sorgulama yeteneğini yitirmiş bir beyindir".

Öğretmenlerin eleştirel düşünmeye bakış açılarının belirlenmesi, bu yöndeki eksiklerinin giderilmesi öğretmen yetiştirme programları için önemlidir. Farklı ölçekler, yöntemler ve örneklem kullanılarak eleştirel düşünme algıları belirlenebilir. Ancak bundan sonraki adım öğretmen adaylarının ve öğretmenlerin eleştirel düşünme becerilerini destekleyici deneysel çalışmalar ve eylem araştırmaları planlamak ve uygulamak olmalıdır. 


\section{KAYNAKÇA}

Açışlı, S. (2016). Sınıf öğretmeni adaylarının öğrenme stilleri ile eleştirel düşünme eğilimlerinin incelenmesi. İlköğretim Online, 15(1), 273-285.

Alkın, Şahin, S. \& Gözütok, D. (2013). Eleştirel düşünmeyi destekleyen öğretmen davranışları envanteri (EDDÖDE): Geliştirilmesi ve uygulanması. Eğitim Bilimleri Araştırmaları Dergisi, 3 (2), 223-254.

Aybek, B. (2015). Düşünme ve eleştirel düşünme. B. Duman (Ed.), Öğretim İlke ve Yöntemleri, (388-417). Ankara: Anı Yayıncılık.

Bailin, S. (2002). Critical thinking and science education. Science and Education, 11, 361375.

Beşoluk, Ş. \& Önder, İ. (2010). Öğretmen adaylarının öğrenme yaklaşımları, öğrenme stilleri ve eleştirel düşünme eğilimlerinin incelenmesi. İlköğretim Online, 9(2), 679-693.

Beyer, B.K. (1987). Practical strategies for the teaching of thinking. London: Allyn \& Bacon.

Branch, J. B. (2000). The relationship among critical thinking,clinical decision-making, and clinical practica: A comparative study. Unpublished doctoral dissertation.University of Idaho.

Bulut, S., Ertem G. \& Sevil, Ü. (2009). Hemşirelik öğrencilerinin eleştirel düşünme düzeylerinin incelenmesi. Dokuz Eylül Üniversitesi Hemşirelik Yüksekokulu Elektronik Dergisi, 2(2), 27-38.

Cüceloğlu, D. (2008). İyi düşün doğru karar ver. Ankara: Remzi Kitabevi.

Doğanay, A. \& Ünal, F. (2006). Eleştirel düşünmenin öğretimi. A. Şimşek (Ed.), İçerik Türlerine Dayalı Öğretim. Ankara: Nobel Yayınevi.

Duron, R., Limbach, B., \& Waugh, W. (2006). Critical thinking framework for any discipline. International Journal of Teaching and Learning in Higher Education, 17(2), 160-166.

Gaforth, D. (1999). ). Deitho: A support tool for learning critical thinking. http://print.cps.nl/colgary//5html. 06/18/2016.

Gelder, T.V. (2005). Teaching critical thinking, some lessons from cognitive science. College Teaching, 53(1), 41-46.

Gokhale, A. A. (2012). Collaborative learning and critical thinking. M. Noebert \& M. Seel (Ed,), Encyclopedia of the sciences of learning. (634-636). Springer.

Halpern, D. F. (1999). Teaching for critical thinking: helping college students develop the skills and dispositions of a critical thinker. New Directions for Teaching and Learning, $80,69-74$.

Hoaglund, J. (1993). Critical thinking: A socratic model. Argumentation, 7, 291-311.

Innabi, H. (2003). Aspects of critical thinking in classroom instruction of secondary school mathematics teachers in Jordan. The Mathematics Education into the 21st Century Project Proceedings of the International Conference The Decidable and the Undecidable in Mathematics Education. Brno, Czech Republic.

İpşiroğlu, Z. (2004). Eğitimde yeni arayışlar. İstanbul: Adam Yayınları.

Johnson, A. (2000). Using creative and critical thinking skills to enhance learning. Boston: Allyn and Bacon. 
Kızıltaş, Y. (2011). Sınıf öğretmeni adaylarının ve sınıf öğretmenlerinin eleştirel düşünme eğilimlerinin çeşitli değişkenler açısından incelenmesi (Van İli Örneği). Yayımlanmamış yüksek lisans tezi, Yüzüncü Yıl Üniversitesi Sosyal Bilimleri Enstitüsü, Van.

Kim, K., Sharma, P., Land, S. M. \& Furlong, K. P. (2013). Effects of active learning on enhancing student critical thinking in an undergraduate general science course. Innovative Higher Education, 38(3), 223-235.

Korkmaz, Ö. (2009). Öğretmenlerin eleştirel düşünme eğilim ve düzeyleri. Ahi Evran Üniversitesi Kırşehir Eğitim Fakültesi Dergisi, 10(1), 1-13.

Kuvaç, M. \& Koç, I. (2014). Fen bilgisi öğretmen adaylarının eleştirel düşünme eğilimleri: İstanbul Üniversitesi örneği. Turkish Journal of Education, 3(2), 46-59.

Loewenstein, G. (1994). The psychology of curiosity: A review and reinterpretation. Psychological Bulletin, 116(1), 75-98.

Lu, K. Y. L., Ho, I. T., Hau, K-T. \& Lai, E. C. M. (2014). Integrating direct and inquiry-based instruction in the teaching of critical thinking: An intervention study. Instructional Science, 42(2), 251-269.

Maltepe, S. (2016). Critical thinking dispositions of pre-service Turkish language teachers and primary teachers. Journal of Education and Training Studies, 4(6), 44-50.

Miles, M. B. \& Huberman, A. M. (1994). An expanded sourcebook: Qualitative data analysis (2nd ed.). Thousand Oaks: Sage.

Muis, K. R., Psaradellis, C., Lajoie, S. P., Leo, I. D. \& Chevrier, M. (2015). The role of epistemic emotions in mathematics problem solving. Contemporary Educational Psychology, 42, 172-185.

Özden, Y. (2005). Öğrenme ve öğretme. Ankara: PegemA Yayıncılık.

Parmaksız, R.Ş. (2015). Üst düzey düşünme becerilerinin öğretimi. Öğretim İlke ve Yöntemleri. (ed. T.Y.Yelken ve C.Akay). Ankara, Anı Yayıncılık, 223-252.

Paul, R. (1992). Critical thinking: What, why, and how. C. Barnes (Ed.). Critical thinking: Educational imperative (3-24). Jossey-Bass: San Francisco.

Paul, R. \& Elder, L. (2013). Kritik düşünce. (Çev. E. Aslan ve G. Sart). Nobel Yayıncılık, Ankara.

Pekdoğan, S. \& Bayar, A. (2016). Üniversite öğrencilerinin eleştirel düşünme eğilimleri ve bilimsel tutumlarının farklı değişkenler açısından incelenmesi. Turkish Studies, 11(9), 669-682.

Potts, B. (1994). Strategies for teaching critical thinking. ERIC Clearinghouse on Assessment and Evaluation, The Catholic University of America, Department of Education, O'Boyle Hall, Washington, OC. ERIC-Education Resources Information Center, (ERIC Document Reproduction Service No: ED385606).

Schafersman, S. D. (1991). An introduction to critical thinking. http://smartcollegeplanning.org. 12/04/2016.

Smith, G. F. (2003). Beyond critical thinking and decision making: Teaching business students how to think. Journal of Management Education, 27(1), 24-51. 
Şen, Ü. (2009). Türkçe öğretmeni adaylarının eleştirel düşünme tutumlarının çeşitli değişkenler açısından incelenmesi. Journal of World of Turks, 1(2), 69-89.

Şengül, C. \& Üstündağ, T. (2009). Fizik öğretmenlerinin eleştirel düşünme eğilimi düzeyleri ve düzenledikleri etkinliklerde eleştirel düşünmenin yeri. Hacettepe Üniversitesi Eğitim Fakültesi Dergisi, 36, 237-248.

Şenlik, N. Z., Balkan, Ö. \& Aycan, Ş. (2011). Öğretmen adaylarının eleştirel düşünme becerileri: Muğla Üniversitesi örneği. Celal Bayar Üniversitesi Fen Bilimleri Dergisi, 7(1), 67-76.

Tabor, M. (1988). Better student thinking through changing teacher behaviors. Educational Leadership, 4(7), 49.

Tekin,N., Aslan, O. \& Yağız, D. (2016). Fen bilimleri öğretmen adaylarının bilimsel okuryazarlık düzeyleri ve eleştirel düşünme eğilimlerinin incelenmesi. Amasya Üniversitesi Eğitim Fakültesi Dergisi, 5(1), 23-50.

Ten Dam, G. \& Volman, M. (2004). Critical thinking as a citizenship competence: Teaching strategies. Learning and Instruction, 14, 359-379.

Torun, N. (2011). Fen ve teknoloji öğretmenlerinin eleştirel düşünme eğilimleri ile duygusal zeka düzeyleri arasındaki ilişki. Yayımlanmamış yüksek lisans tezi, Çukurova Üniversitesi Sosyal Bilimler Enstitüsü, Adana.

Tümkaya, S. (2011). Fen bilimleri öğrencilerinin eleştirel düşünme eğilimleri ve öğrenme stillerinin incelenmesi. Ahi Evran Üniversitesi Eğitim Fakültesi Dergisi, 12(3), 215234 .

Uluçınar, U. \& Aypay, A. (2016). Eleştirel düşünceye dayalı karar verme modeli. 41(185), 251-268.

Walsh, D. ve Paul, R. (1998). The goal of critical thinking: from educational ideal to educational reality. Washington, D.C. American Federation of Teachers.

Wolcott, S. K., Baril, C. P., Cunningham, B. M., Fordham, D. R. \& Pierre, K. S. (2002). Critical thought on critical thinking research. Jounal of Accounting Education, 20, 85103.

Yazçayır, N. (2015). Düşünme temelli öğrenme modelleri. Y. Budak. (Ed.), Öğretim İlke ve Yöntemleri. (191-254). Ankara: PegemA Yayıncılık.

Yıldırım, A. \& Şimşek, H. (2013). Sosyal bilimlerde nitel araştırma yöntemleri (9. bask1). Ankara: Seçkin Yayıncılık.

Zayıf, K. (2008). Öğretmen adaylarının eleştirel düşünme eğilimleri. Yayımlanmamış yüksek lisans tezi, Abant İzzet Baysal Üniversitesi Sosyal Bilimler Enstitüsü, Bolu. 